\title{
Oxidative processes during 'Golden' papaya fruit ripening
}

\section{Evellyn Couto Oliveira Resende', Paula Fabiane Martins², Ricardo Antunes de Azevedo², Angelo Pedro Jacomino ${ }^{3}$, Ilana Urbano Bron ${ }^{1 *}$}

\author{
${ }^{1}$ Agronomic Institute, Posthaverst Laboratory, Campinas, SP, Brazil. \\ 2Department of Genetics, "Luiz de Queiroz" College of Agriculture, University of São Paulo (USP), \\ Piracicaba, SP, Brazil. \\ ${ }^{3}$ Department of Crop Science, "Luiz de Queiroz" College of Agriculture, University of São Paulo (USP), \\ Piracicaba, SP, Brazil.
}

*Corresponding author: ilana@iac.sp.gov.br

Received: 26 April 2012 Accepted: 29 June 2012

\begin{abstract}
'Golden' papayas at maturity stage 1 (15\% yellow skin) were chosen to study selected oxidative processes, the activity of antioxidant enzymes and lipid peroxidation in storage at $22^{\circ} \mathrm{C}$, during the ripening of the fruit. An increase in ethylene production was observed on the second day of storage and it was followed by an increase in respiration. An increased activity of catalase, glutathione reductase and ascorbate peroxidase was observed concurrently or soon after this increase in ethylene production and respiration. The increased activity of these enzymes near the peaks of ethylene production and respiration is related to the production of oxidants accompanying the onset of ripening. On the fourth day of storage, there was an increased lipid peroxidation and decreased activities of catalase, glutathione reductase and superoxide dismutase. Lipid peroxidation induces the increase of antioxidant enzymes, which can be verified by further increases in the activities of catalase, glutathione reductase, superoxide dismutase and ascorbate peroxidase. Unlike the other antioxidant enzymes, the ascorbate peroxidase activity in the pulp increased continuously during ripening, suggesting its important role in combating reactive oxygen species during papaya ripening. With regard to physical-chemical characteristics, the soluble solids did not vary significantly, the acidity and ascorbic acid contents increased, and hue angle and firmness decreased during storage. The results revealed that there was variation in the activity of antioxidant enzymes, with peaks of lipid peroxidation during the ripening of 'Golden' papaya. These results provide a basis for future research, especially with regard to the relationships among the climacteric stage, the activation of antioxidant enzymes and the role of ascorbate peroxidase in papaya ripening.
\end{abstract}

Keywords: Carica papaya, antioxidant system, climacteric, ethylene, lipid peroxidation.

Abbreviations: APX: ascorbate peroxidase; BSA: bovine serum albumin; CAT: catalase; DDT: dithiothreitol; EDTA: ethylene diamine tetraacetic acid; GR: glutathione reductase; $\mathrm{H}_{2} \mathrm{O}_{2}$ : hydrogen peroxide; PVPP: polyvinylpolypyrrolidone; $\mathrm{O}_{2} \cdots$ superoxide; $\mathrm{OH}:$ hydroxyl radical; ROS: reactive oxygen species; SOD: superoxide dismutase; SS: soluble solids; TBA: thiobarbituric acid.

\section{INTRODUCTION}

Ripening is a complex event that has been described as an oxidative phenomenon that is accompanied by peroxidative damage and the loss of membrane integrity (Thompson, 1984). Increase in ion leakage, decrease in plasma membrane fluidity, loss of membrane integrity and accumulation of lipid peroxides are found in fruits, such as melons (Lester and Stein, 1993), apples (Lurie and BenArie, 1983) and tomatoes (Palma et al., 1995). Oxidative damage in tissues is caused by the accumulation of ROS, such as $\mathrm{O}_{2}^{--}, \mathrm{H}_{2} \mathrm{O}_{2}$ and $\mathrm{OH}^{-}$. 
During the early stages of fruit ripening, the antioxidant system protects the fruit from the destructive effects of gradual oxidative stress; this complex system includes antioxidant enzymes, such as CAT, SOD, APX and GR. During the more advanced stages of ripening, oxidative damage occurs due to the overproduction and accumulation of ROS (Del Río et al., 1998) or due to a loss of the capacity of the antioxidant system to eliminate these species (Kanazawa et al., 2000). Free radicals induce a series of cell damage, including lipid peroxidation (Dhindsa et al., 1982), which initiates the destructive changes associated with ripening (Du and Bramlage, 1994; Meir et al., 1991). Therefore, ripening can be considered a stressful process, with a progressive increase in oxidation (Rogiers et al., 1998), that is, as a functionally modified form of senescence. The oxidative stress during ripening and senescence has been reported in species such as tomatoes (Mondal et al., 2004), mangoes (Singh and Dwivedi, 2008), and peaches (Camejo et al., 2010), but few studies on this topic have been conducted with tropical species.

Papaya is a much appreciated tropical fruit with great economic importance. Studies have been conducted on certain aspects of the biochemistry of papaya ripening (Bron and Jacomino, 2006; Bron et al., 2006); however, there is little information about the antioxidant system of the fruit and oxidative stress during this phase. The aim of this study was to examine selected oxidative processes during 'Golden' papaya ripening by evaluating the activity of antioxidant enzymes and lipid peroxidation.

\section{MATERIAL AND METHODS}

Plant material and experimental design: Golden variety papaya (Carica papaya L.) was used in a maturity stage 1 (15\% yellow skin) (Bron et al., 2006). The fruits were purchased in a local market and stored at $22 \pm 1.5^{\circ} \mathrm{C}$ and 85 to $95 \% \mathrm{RH}$ for 9 days. The fruits were evaluated daily for respiration, ethylene production, lipid peroxidation, antioxidant enzymes, firmness and skin color, and on alternate days for the titratable acidity, SS and ascorbic acid content.

The experimental design was completely randomized. All of the physical and chemical analyses were performed with three replicates, each composed of a single fruit. The measurements of respiration and ethylene production were performed with ten repetitions. Data were analyzed using ANOVA and Tukey's test $(p<0.05)$ for comparison of the means.
Physicochemical analysis: The pulp firmness was evaluated using a digital penetrometer (53200, Tr Turoni, Italy), with an 8-mm tip, obtaining a direct reading in the region of greatest diameter by removing part of the skin (thin layer). Data were expressed in Newtons (N) (Bron and Jacomino, 2009).

Skin color was determined using a colorimeter (Minolta CR-300, Japan), obtaining two readings per fruit in the region of largest diameter. The results were expressed in ${ }^{\circ} \mathrm{Hue}\left({ }^{\circ} \mathrm{H}\right)$, considering the average of the two readings (Bron and Jacomino, 2009).

For the determination of SS, the fruit pulp was centrifuged, and two drops of juice were placed on a digital refractometer (Atago PR-101, Japan). Two readings were obtained, and the result was an average expressed as ${ }^{\circ}$ Brix (Bron and Jacomino, 2009).

The amount of titratable acidity was determined according to Carvalho et al. (1990), titrating the juice with sodium hydroxide $(\mathrm{NaOH}) 0.1 \mathrm{~N}$. The results were expressed as the percentage of citric acid.

The amount of ascorbic acid was determined by adding $5 \mathrm{~g}$ of papaya pulp to $25 \mathrm{~mL}$ of $1 \%$ oxalic acid and then titrating this solution with DCFI (2,6-dichlorophenolindophenol sodium) until the pink color persisted for 15 seconds. The results were expressed as $\mathrm{mg}$ of ascorbic acid per $100 \mathrm{~g}$ of pulp (Bron and Jacomino, 2009).

Respiration and ethylene production: Respiratory activity and ethylene production were measured using the method described by Bron and Jacomino (2009). The gas samples were analyzed with a gas chromatographer (Thermo Finnigan Trace 2000GC, Italy) equipped with a capillary Porapack column $(2 \mathrm{~m})$ set at $100^{\circ} \mathrm{C}$, with hydrogen as carrier gas at $10^{5} \mathrm{~Pa}$ pressure. Respiration and ethylene production were determined by the difference between the initial (when the vials were closed) and final (after 1 hour) gas concentration, expressed as $\mathrm{mL}$ of $\mathrm{CO}_{2} \mathrm{~kg}^{-1} \mathrm{~h}^{-1}$ and $\mu \mathrm{L}$ of $\mathrm{C}_{2} \mathrm{H}_{4} \mathrm{~kg}^{-1} \mathrm{~h}^{-1}$, respectively.

Lipid peroxidation: The lipid peroxidation was measured using $1.0 \mathrm{~g}$ of pulp and $0.5 \mathrm{~g}$ of the skin and evaluated by the production of metabolites, mainly malondialdehyde (MDA), reactive with 2-TBA (Mihara et al., 1980). The lipid peroxidation was determined spectrophotometrically at 535 and $600 \mathrm{~nm}$. The amount of MDA was expressed in mM of MDA $g^{-1}$ of fresh tissue using an extinction coefficient of the reaction of $155 \mathrm{mM} \mathrm{cm}^{-1}$. 
Extraction of proteins: The samples were collected from the skin and pulp from the middle portion of the fruits and were soaked in liquid $\mathrm{N}_{2}$ until the material had the appearance of flour. The samples were homogenized in potassium phosphate buffer $100 \mathrm{mM}, \mathrm{pH} 7.5$ (ratio of $1 \mathrm{~g}$ of sample: $2 \mathrm{~mL}$ of buffer), containing $1 \mathrm{mM}$ EDTA, $3 \mathrm{mM}$ DTT and 4\% (w/v) PVPP, according to Azevedo et al. (1998).

The homogenate was centrifuged, and the supernatant was divided into aliquots and stored in a freezer at $-80^{\circ} \mathrm{C}$ until analysis of SOD and GR via non-denaturing gels (PAGE) and the activities of CAT, GR and APX using a spectrophotometer. The protein concentration was determined according to Bradford (1976) using BSA as the standard.

Enzymatic activities: The CAT activity was determined spectrophotometrically by the decomposition of $\mathrm{H}_{2} \mathrm{O}_{2}$ for 1 minute through the changes in absorbance at $240 \mathrm{~nm}$ at $25^{\circ} \mathrm{C}$, as described by Kraus et al. (1995) and with some modifications, according to Azevedo et al. (1998). The results were expressed as $\mathrm{mmol} \mathrm{min}^{-1} \mathrm{mg}^{-1}$ of protein.

The APX activity was determined by monitoring the rate of ascorbic acid oxidation, as observed by the decrease in absorbance at $290 \mathrm{~nm}$ over 1 minute. (Nakano and Asada, 1981). The activity was expressed in $\mu \mathrm{mol} \mathrm{min}^{-1} \mathrm{mg}^{-1}$ of protein using the extinction coefficient of $2.8 \mathrm{mM} \mathrm{cm}^{-1}$.

The GR activity was determined by the reduction of oxidized glutathione, followed by the monitoring of the change in absorbance at $412 \mathrm{~nm}$ for 1 minute at $30^{\circ} \mathrm{C}$ (Gomes-Junior et al., 2006). The results were expressed as $\mu \mathrm{mol} \mathrm{min} \mathrm{mg}^{-1} \mathrm{mg}^{-1}$ of protein.

The activities of GR and SOD were determined using non-denaturing gel electrophoresis (12\% PAGE) of the protein extracts (Azevedo et al., 1998). The pattern of $20 \mu \mathrm{g}$ of fruit protein extract was compared with those of the SOD and GR in beef liver (Sigma - 2 units). After separation of the proteins, the SOD activity was determined according to Gomes-Junior et al. (2006), and the GR activity was determined according to Lee and Lee (2000). For the determination of the isoforms of SOD, $100 \mu \mathrm{g}$ protein was electrophoresed under the same conditions described above. At the end of the electrophoresis, the isoenzymes were classified as Mn-SOD, Fe-SOD or $\mathrm{Cu} / \mathrm{Zn}-\mathrm{SOD}$ based on their resistance to inhibitors: Mn-SOD is resistant to both $\mathrm{KCN}$ and $\mathrm{H}_{2} \mathrm{O}_{2}$; $\mathrm{Fe}-\mathrm{SOD}$ is resistant to $\mathrm{KCN}$ and inhibited by $\mathrm{H}_{2} \mathrm{O}_{2}$; and $\mathrm{Cu} / \mathrm{Zn}-\mathrm{SOD}$ is inhibited by both (Azevedo et al., 1998).

\section{RESULTS}

The papaya fruits demonstrated a peak in ethylene production $(p<0.05)$ on the second day of storage and two peaks of respiration on the third and eighth days of storage (Figure 1). During ripening, the respiration of the fruits nearly doubled, ranging from 11.0 to $21.8 \mathrm{~mL}$ of $\mathrm{CO}_{2} \mathrm{~kg}^{-1} \mathrm{~h}^{-1}$. The ethylene production increased by

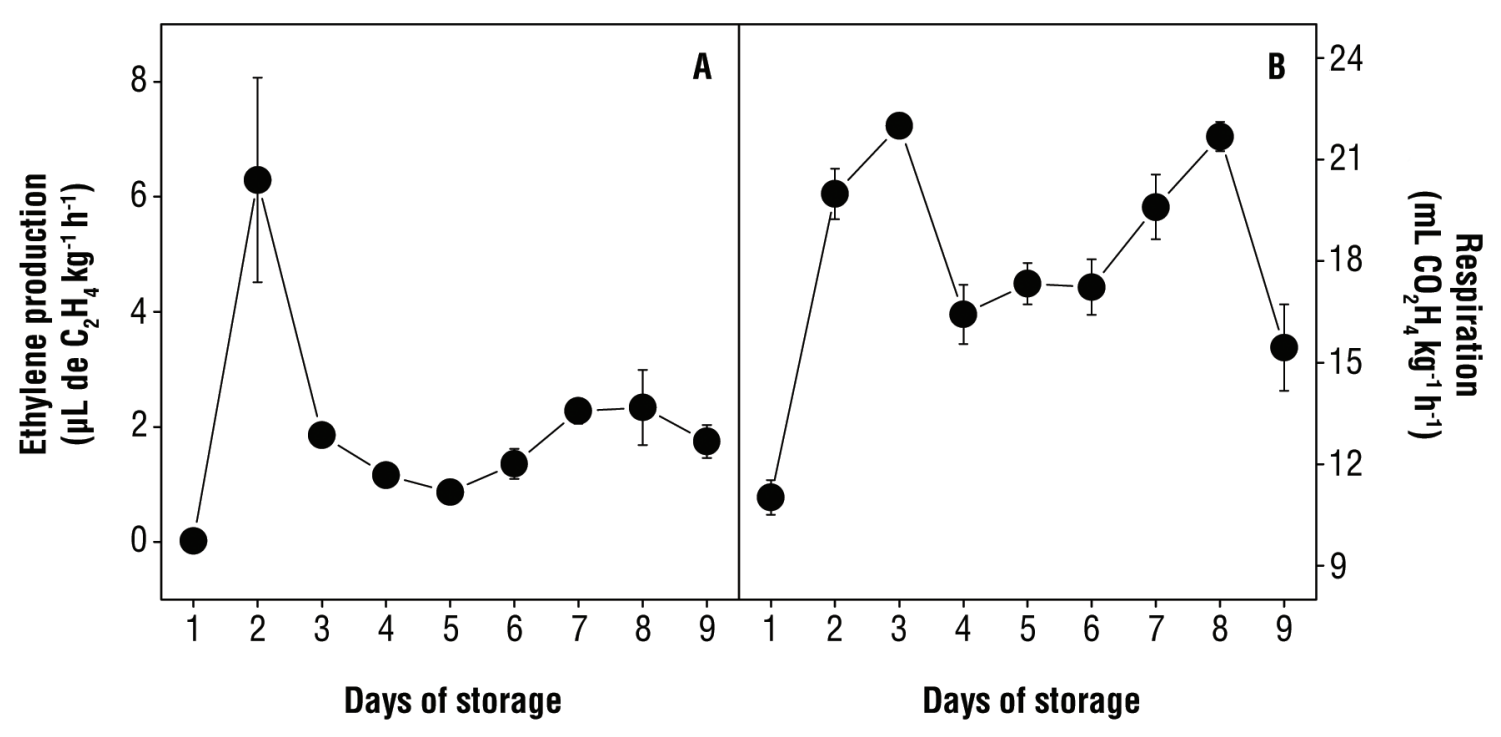

Figure 1. Ethylene production (A) and respiration (B) of 'Golden' papaya stored at $22 \pm 1.5^{\circ} \mathrm{C}$ and 85 to $95 \%$ RH during 9 days. Vertical bars indicate the standard error $(n=3)$. 
approximately six fold, from 0.02 to $6.3 \mu \mathrm{L}$ of $\mathrm{C}_{2} \mathrm{H}_{4} \mathrm{~kg}^{-1} \mathrm{~h}^{-1}$, during the ripening process (Figure 1).

From the beginning of ripening, CAT activity was higher in the skin when compared with the pulp, and there were changes in the CAT activity, with a peak activity $(p<0.05)$ in the pulp after 3 days ( $70 \mu \mathrm{mol} \mathrm{min}^{-1} \mathrm{mg}^{-1}$ of protein) (Figure 2B). During the first 4 days, CAT activity remained constant in the papaya skin, at approximately $111.9 \mu \mathrm{mol} \mathrm{min}{ }^{-1} \mathrm{mg}^{-1}$ of protein. Over the course of ripening, CAT activity in the skin was variable but showed no difference from the initial values at the end of the study period (Figure 2A).

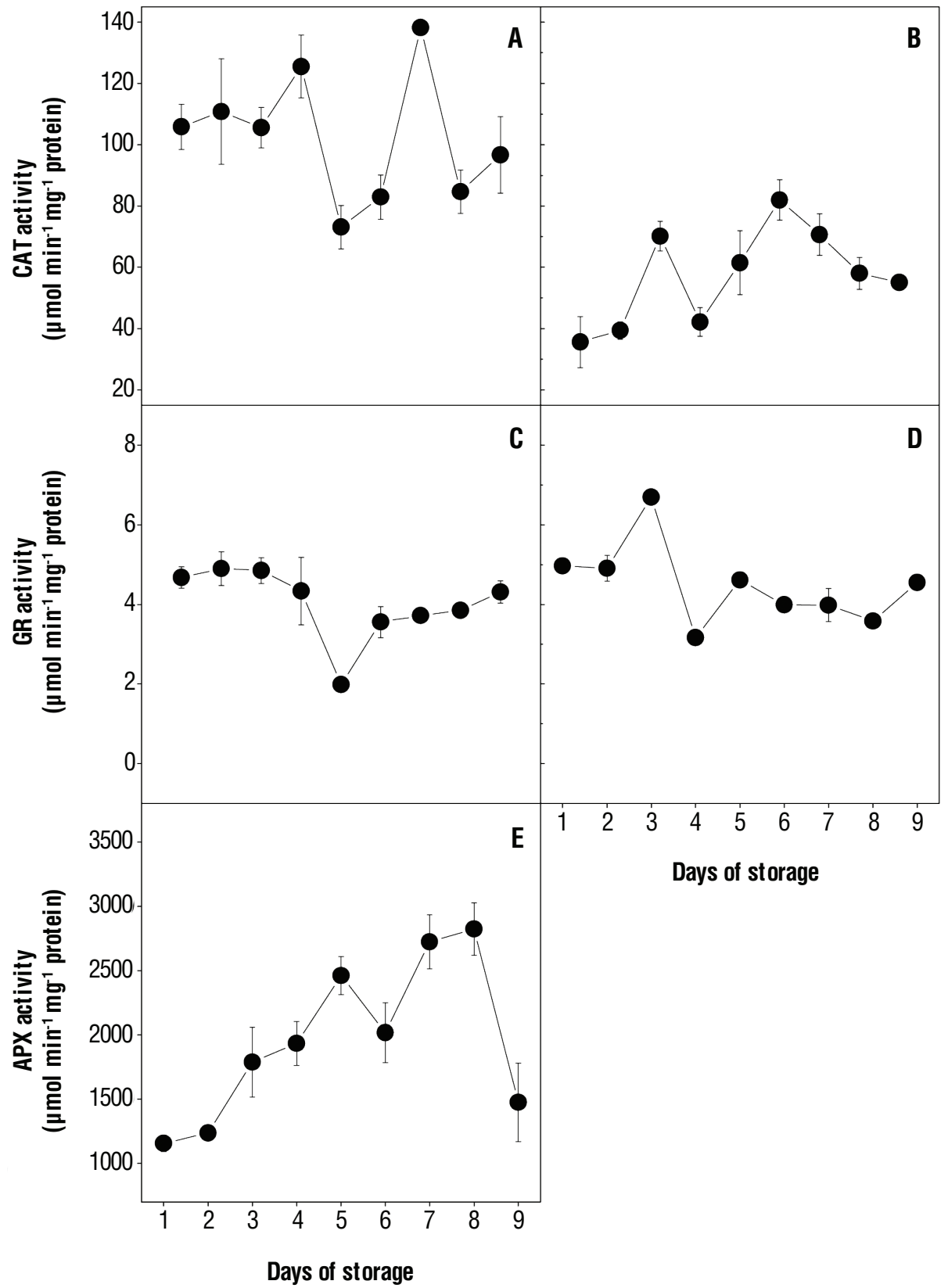

Figure 2. Catalase (CAT) activity in skin (A) and pulp (B); glutathione reductase (GR) activity in skin (C) and pulp (D) and ascorbate peroxidase (APX) in pulp (E) of 'Golden' papaya stored at $22 \pm 1.5^{\circ} \mathrm{C}$ and 85 to $95 \%$ RH during 9 days. Vertical bars indicate the standard error of mean $(n=3)$. 
In contrast to what was observed for CAT, the GR activity was similar when comparing the pulp with the skin, and an enzymatic activity peak $(p<0.05)$ was observed in the pulp on the third day of storage $\left(6.7 \mathrm{mmol} \mathrm{min}^{-1} \mathrm{mg}^{-1}\right.$ of protein). Thereafter, the enzyme activity remained constant, with mean values of $4.1 \mu \mathrm{mol} \mathrm{min}{ }^{-1} \mathrm{mg}^{-1}$ of protein by the end of the analysis. Both in the skin and the pulp, the GR activity at the end of the study period was similar to the early-ripening values (Figures $2 \mathrm{C}$ and $\mathrm{D}$ ).

The GR activity was also determined by nondenaturing PAGE analysis. In the skin of papaya, there was a greater intensity of the protein bands during the first four days of storage, and the same number of GR isoforms was found in the skin and pulp. In the pulp, the intensity of isoforms I and II were essentially the same during ripening, whereas isoform III exhibited variable intensity during the study period (Figure 3).

The activity of APX was detected only in the pulp of the papaya fruits, displaying a gradual increase in activity that reached a maximum on the eighth day $\left(2823.48 \mu \mathrm{mol} \mathrm{min}^{-1} \mathrm{mg}^{-1}\right.$ of protein) $(p<0.05)$. The activity of APX markedly decreased thereafter (Figure 2E).

The samples of both the skin and the pulp demonstrated five SOD isoenzymes (I, II, III, IV and V) via PAGE. The SOD activity did not vary significantly in the papaya pulp, with similar band intensities during the 9 days of storage. Furthermore, in both the pulp and skin, isoenzymes III and IV demonstrated higher activities, as characterized by higher band intensities when compared with isozymes I, II and V (Figure 3). Cu/Zn-SOD was identified in both the skin and pulp samples, whereas FeSOD and Mn-SOD isozymes were not found, indicating that the $\mathrm{Cu} / \mathrm{Zn}-\mathrm{SOD}$ is probably the predominant isozyme in papaya (Figure 4).

The lipid peroxidation, determined through the quantification of MDA, remained low during the first 3 days of ripening in both the skin and pulp. On the fourth day of fruit storage, lipid peroxidation reached a peak $(1.12 \mathrm{mM}$ of $\mathrm{MDA} \mathrm{g}^{-1}$ of fresh weight) $(p<0.05)$ in the pulp, returning values similar to the beginning of ripening $(0.55 \mathrm{mM}$ of MDA g-1 of fresh weight) after 9 days (Figure 5B). In contrast to the pulp, no clear peak was observed in the skin of the papayas, but increased peroxidation was observed until the seventh day $\left(0.83 \mathrm{mM}\right.$ of $\mathrm{MDA} \mathrm{g}^{-1}$ of fresh weight) of storage $(p<0.05)$ (Figure $5 A)$.

There was a marked decrease in pulp firmness until the third day of storage, from $114.5 \mathrm{~N}$ to $15.8 \mathrm{~N}(\mathrm{p}<0.05)$ (Figure 6B). The papaya skin color varied significantly,
GR - Skin

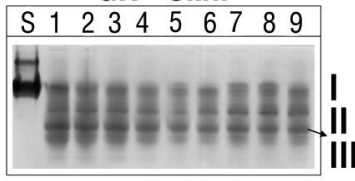

GR - Pulp

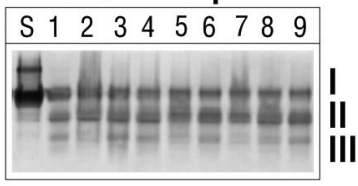

SOD - Skin

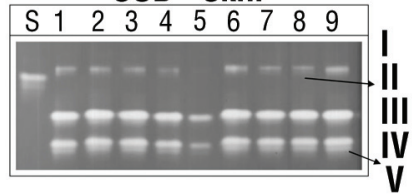

SOD - Pulp

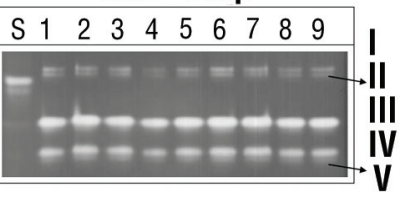

Figure 3. Glutathione reductase (GR) and superoxide dismutase (SOD) activities in PAGE of 'Golden' papaya stored at $22 \pm 1.5^{\circ} \mathrm{C}$ and 85 to $95 \%$ RH during 9 days. S=Bovine liver GR and SOD standards. Numbers 1 to 9 presented the days of storage of fruits. Roman numerals presented the isoforms of GR and SOD.

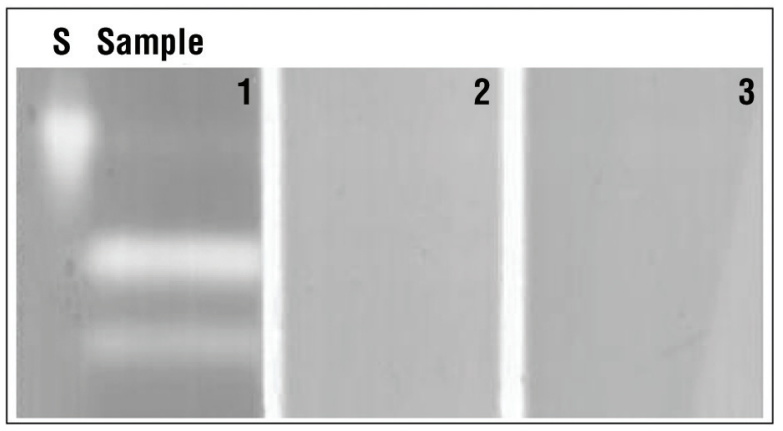

Figure 4. Characterization of superoxide dismutase (SOD) isoenzymes in PAGE of 'Golden' papaya stored at $22 \pm 1.5^{\circ} \mathrm{C}$ and 85 to $95 \%$ RH during 9 days. S=Bovine liver SOD standard; $1=$ Control; 2=Presence of KCN; $3=$ Presence of $\mathrm{H}_{2} \mathrm{O}_{2}$.

presenting a reduction in the angle of $105.9^{\circ} \mathrm{H}$ to $80.9^{\circ} \mathrm{H}$ $(p<0.05)$ during the ripening process (Figure 6A). There was no change in the SS content of the papaya fruits during ripening (Table 1), with an average value of $10.9^{\circ}$ Brix. There was a slight increase in the acid levels, between 0.08 and $0.10 \%$ of citric acid during the ripening process (Table 1 ). The ascorbic acid increased significantly during ripening, reaching $96.3 \mathrm{mg}$ of ascorbic acid $100 \mathrm{~g}^{-1}$ of pulp, which is nearly twice that at the beginning of ripening (Table 1).

\section{DISCUSSION}

In this study, 'Golden' papaya showed a typical climacteric pattern of respiration, and the increase in ethylene production was accompanied by respiration 


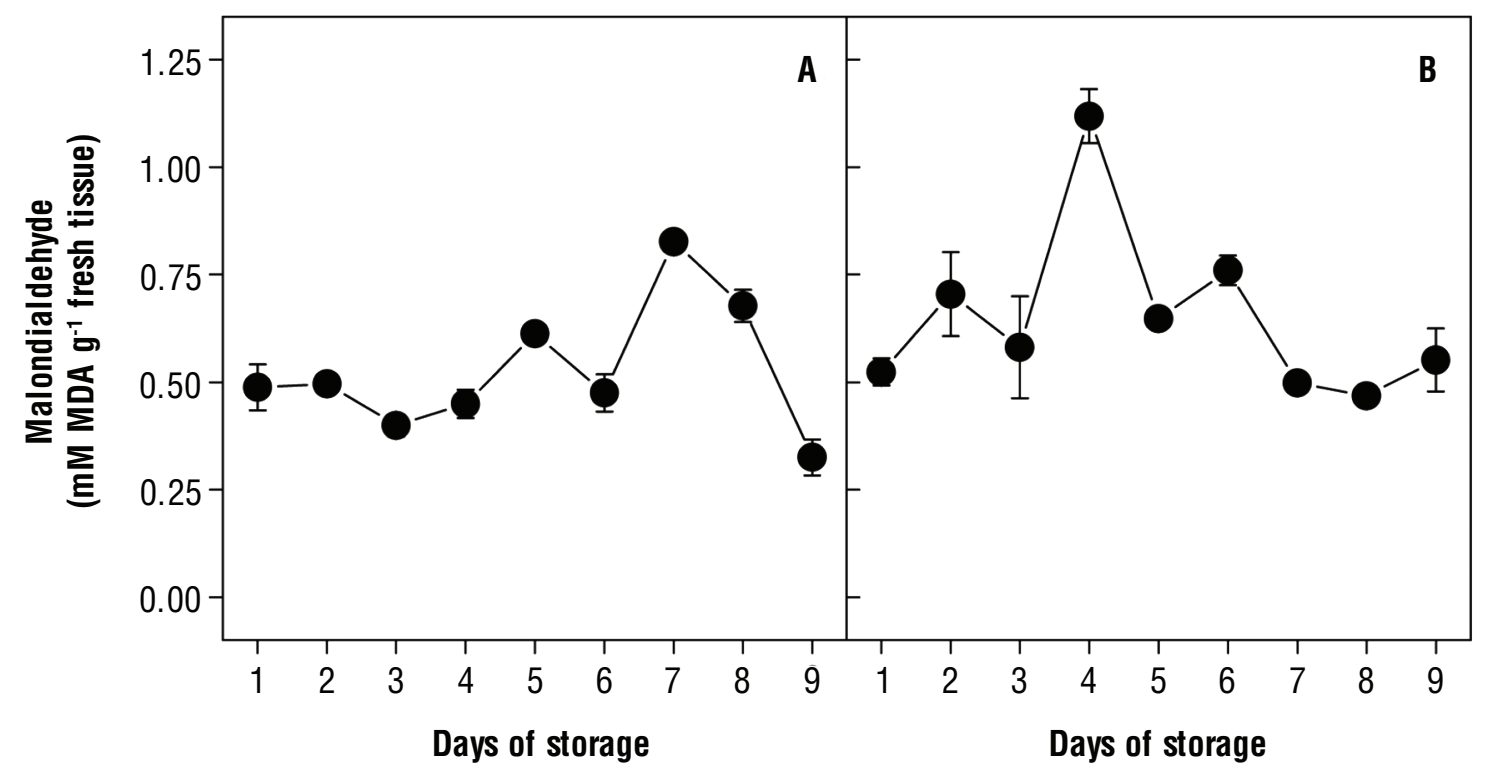

Figure 5. Malondialdehyde (MDA) in skin (A) and pulp (B) of 'Golden' papaya stored at $22 \pm 1.5^{\circ} \mathrm{C}$ and 85 to $95 \% \mathrm{RH}$ during 9 days. Vertical bars indicate the standard error of mean $(n=3)$.

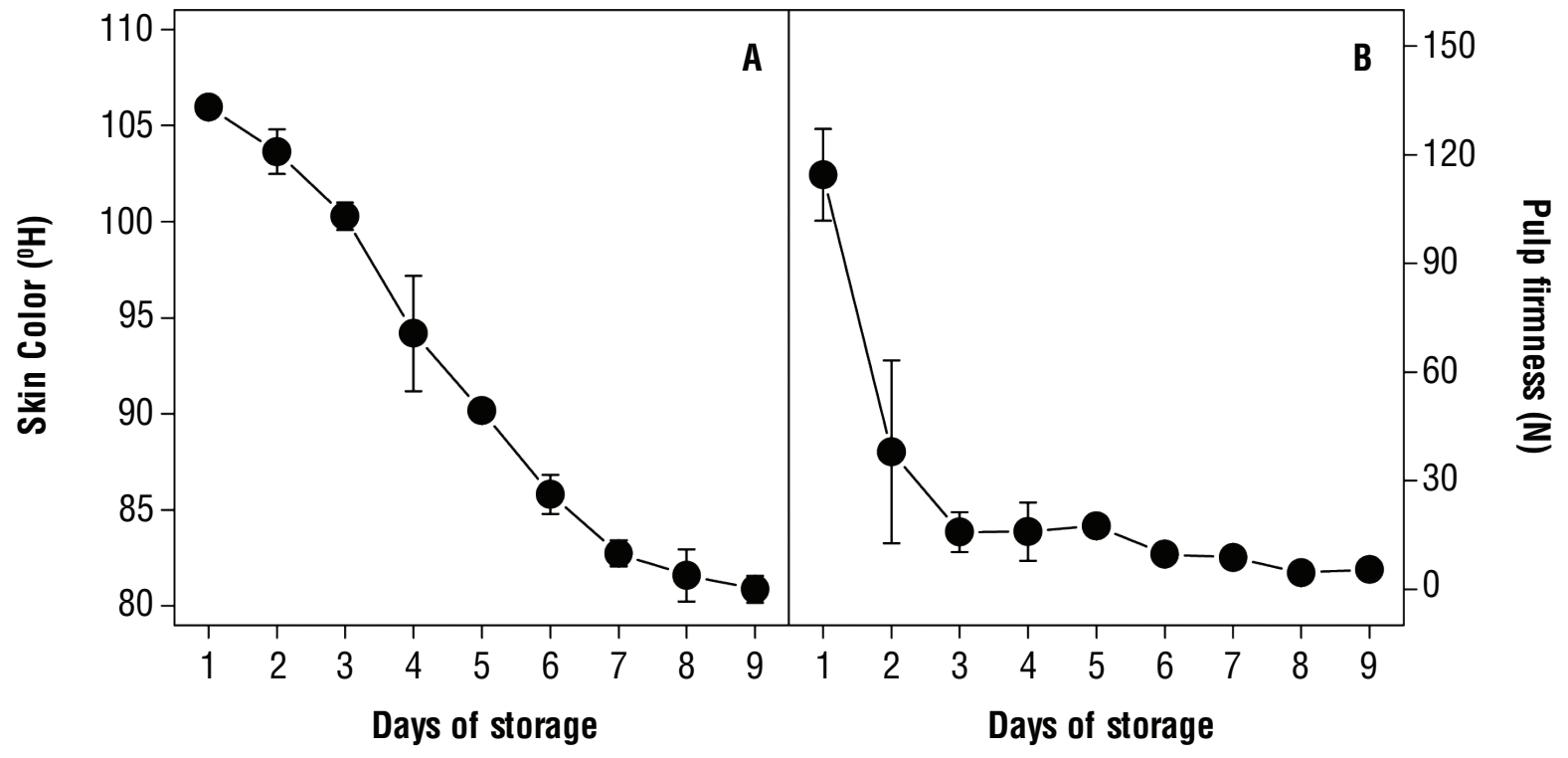

Figure 6. Skin color (A) and pulp firmness (B) of 'Golden' papaya stored at $22 \pm 1.5^{\circ} \mathrm{C}$ and 85 to $95 \%$ RH during 9 days. Vertical bars indicate the standard error of mean $(n=3)$.

Table 1. Soluble solids, acidity and ascorbic acid content of 'Golden' papaya stored at $22 \pm 1.5^{\circ} \mathrm{C}$ and 85 to $95 \%$ RH during 9 days *

\begin{tabular}{|c|c|c|c|c|c|c|c|c|c|c|c|}
\hline \multirow{2}{*}{ Variables } & \multicolumn{10}{|c|}{ Days of storage } & \multirow{3}{*}{$\begin{array}{c}\text { CV (\%) } \\
2.6\end{array}$} \\
\hline & \multicolumn{2}{|c|}{1} & \multicolumn{2}{|c|}{3} & \multicolumn{2}{|c|}{5} & \multicolumn{2}{|c|}{7} & \multicolumn{2}{|c|}{9} & \\
\hline Soluble solids ( ${ }^{\circ}$ Brix) & 10.7 & a & 11.2 & $\mathrm{a}$ & 10.6 & a & 10.8 & $\mathrm{a}$ & 10.9 & a & \\
\hline Acidity ( $\%$ of citric acid) & 0.08 & $b$ & 0.10 & a & 0.10 & a & 0.10 & $\mathrm{a}$ & 0.10 & $\mathrm{a}$ & 3.2 \\
\hline Ascorbic Acid Content (mg $100 \mathrm{~g}^{-1}$ of pulp) & 52.8 & c & 82.3 & $\mathrm{bc}$ & 91.4 & $\mathrm{a}$ & 90.4 & $a b$ & 96.3 & $\mathrm{a}$ & 3.5 \\
\hline
\end{tabular}

*Means followed for the same letter, in the line, not differ each other by Tukey test at $5 \%$ of probability.

CV: coefficient of variation. 
peak (Figure 1). A study of 'Golden' papaya conducted by Jacomino et al. (2002) reported an increased production of ethylene prior to the rise of the climacteric respiration. It can be observed that the respiration and ethylene production happen next, but it is clear that the peak of respiration is not necessarily detected after the climacteric rise in ethylene. Biale and Young (1982) have indicated that the increase in ethylene production during the climacteric stage can begin early, occurring simultaneously with or after the peak of climacteric respiration. This behavior promotes disagreement if ethylene is the initiator of the climacteric, and if its endogenous production is the signal for triggering the biochemical and physiological changes during climacteric (Saltveit, 1993).

Romani (1984) proposed that the climacteric stage reflects the maximum homeostatic response of mitochondria to compensate for the degrading effects of cellular senescence and that increases in the ethylene production are also a response to cellular stress. However, an increase in ethylene production prior to the rise of climacteric respiration possibly indicates the promoting effect of ethylene on the respiration process and, as with respiration, is an active source of ROS (Purvis et al., 1995). The climacteric rise in respiration is probably a contributor to the increase in oxidative stress during this phase of development, promoting the production of cellular oxidants (Rich and Bonner, 1978). Leshem et al. (1986) also showed that, at the beginning of fruit ripening, the increase in ethylene production is accompanied by the natural rise of $\mathrm{H}_{2} \mathrm{O}_{2}$ and other ROS.

The natural increase of ROS activates the antioxidant system, and SOD and CAT are more effective than other antioxidant enzymes in influencing the patterns of fruit ripening (Masia, 1998). In the present study, we observed increased activity of CAT and GR in the papaya pulp on the third day of storage (Figures 2B and D). These activity increases in the pulp occurred after the increase in ethylene production and simultaneously with the increase in the papaya respiration (Figure 1). This increase in enzyme activities close to the peak of ethylene production and respiration is probably related to the production of oxidants at the onset of ripening (Leshem et al., 1986). Masia et al. (1998) showed that the onset of ripening, as indicated by the increase of ethylene, is related to the activities of SOD and CAT, showing that the peak of ethylene production in apples was related to the peak activities of CAT and SOD.

Previous reports indicate that the pattern of antioxidant enzyme activities during ripening varies according to the fruit. In a study with guavas, Mondal et al.
(2009) found a very similar behavior between the SOD and CAT enzymes: there was an increase in antioxidant activity with ripening, followed by a decrease in activity at later stages. Conversely, Mondal et al. (2004) and Reddy and Srivastava (2003) identified significant SOD activity in tomatoes and green mangoes, respectively. Camejo et al. (2010) found a similar activity of SOD in green and mature peaches. In apples (Du and Bramlage, 1994), the SOD activity increased with senescence, whereas there was a decrease in other fruits, such as oranges (Huang et al., 2007).

There are also divergent reports about CAT behavior during ripening. Whereas increasing activities were found in tomatoes during ripening (Andrews et al., 2004; Mondal et al., 2004), CAT activity decreased in oranges (Huang et al., 2007). Dhindsa et al. (1981) observed that SOD activity decreased during the senescence of leaves, but Du and Bramlage (1994) showed that the SOD activity increased during senescence in apples. According to Rogiers et al. (1998), the activities of SOD and CAT were high in green fruits but were reduced by 4 - and 18-fold, respectively, in mature fruit.

During the ripening of mangoes, Singh and Dwivedi (2008) found decreasing activities in SOD and CAT, and the same pattern was observed in oranges by Huang et al. (2007). In guavas, the activities of antioxidant enzymes reached maxima at the stage of color change and decreased at later stages (Mondal et al., 2009). Other authors found continuous increases during ripening (Rogiers et al., 1998; Huang et al., 2007), with marked decreases in the later stages of ripening. Such variation in the behavior of antioxidant enzymes can be attributed to the differences in the activities of isoenzymes.

We observed no significant increase in SOD during ripening (Figure 3). For the characterization of the SOD isoforms (Figure 4), it was analyzed only the sample on the seventh day of storage, assuming that the same banding pattern was observed throughout ripening. We also observed $\mathrm{Cu} / \mathrm{Zn}-\mathrm{SOD}$ and the absence of Fe-SOD and $\mathrm{Mn}-\mathrm{SOD}$ isozymes, indicating that $\mathrm{Cu} / \mathrm{Zn}-\mathrm{SOD}$ is predominantly responsible for the SOD activity in papayas (Figure 4). The high number of isoenzymes suggests that SOD has important role in preventing oxidative damage (Camejo et al., 2010). Therefore, further study is needed in relation to SOD isoforms and the role of organelles in oxidative changes.

Unlike SOD, the APX activity in the pulp (Figure 2E) increased significantly during ripening, suggesting an important role for combating ROS during papaya ripening. 
The APX in muskmelon increased approximately 3 -fold during ripening (Fogelman et al., 2011). Mondal et al. (2009) found that the activity of APX in guavas was low in green fruits and increased with ripening, showing a decrease at the end of fruit development. The same behavior was observed in tomatoes by Andrews et al. (2004) and in papayas by Silva et al. (1990).

If not inactivated, the free radicals formed induce lipid peroxidation (Dhindsa et al., 1982), which initiates the deteriorative changes associated with fruit ripening (Du and Bramlage, 1994; Meir et al., 1991). In our study, the increase of lipid peroxidation (Figures $5 \mathrm{~A}$ and $B$ ) was accompanied by decreases in the activities of CAT (Figures 2A and B), GR (Figures 2C, D and 3 ) and SOD (Figure 3 ) on the fourth and fifth days of storage in the pulp and skin papaya, respectively. Rogiers et al. (1998) showed that oxidative stress during ripening probably occurs as a consequence of reduced activities of key enzymes, such as SOD and CAT, responsible for eliminating ROS.

Changes in oxidative stress during fruit development can be assessed by the degree of lipid peroxidation. Membrane lipids and free fatty acids are highly susceptible to oxidation; therefore, increased oxidative stress is indicated by the accumulation of lipid peroxidation products, which are also evidence of increased oxidative stress during ripening (Rogiers et al., 1998). An increase in oxidative damage, as measured by the production of free radicals and the loss of membrane integrity, is a characteristic of senescence in plant tissues (Dhindsa et al., 1981; Thompson, 1984). As with senescence, fruit ripening is accompanied by the deterioration of cell membranes (Ferrie et al., 1994).

According to Rogiers et al. (1998), increased oxidative stress, which probably results from reductions in the activity of antioxidant enzymes, is necessary to facilitate the metabolic changes associated with ripening fruit. Because the entire process of fruit ripening is considered a functionally modified form of senescence, the mechanism of membrane deterioration during ripening is also likely to be similar to that in senescence (Mondal et al., 2004).

The second increase in respiration that we observed (Figure 1B) on the eighth day of storage seems to be a response to the presence of pathogens, although the papayas used during the experiment showed no visual symptoms of pathogen attack. As fungi can remain in a quiescent state, infections that occur in the field are rarely detectable prior to ripening (Tatagiba et al., 2002).
The results of the physical-chemical evaluations reveal that the papaya matured normally and that the changes are closely related to the production of ethylene (Bron and Jacomino, 2009). The main changes in the physicochemical characteristics (firmness, skin color, and ascorbic acid content) of the papayas were observed after the increase in ethylene production and the respiration peak, as also observed for the enzyme activities.

There was a reduction of the angle color $\left(\mathrm{H}^{\circ}\right)$ in the papaya skin (Figure 6A). In fact, increases in chlorophyllase activity are generally associated with ethylene production during fruit ripening (Tucker, 1993). We found that the fruit firmness decreased during ripening, especially after the maximum production of ethylene, which correlates with the ethylene sensitivity of the fruit softening process (Bron and Jacomino, 2009).

It was observed that the amount of ascorbic acid in the fruits increased markedly during ripening (Table 1). Some studies suggest that mannose and L-galactose are intermediates for the synthesis of ascorbic acid in plants. As these sugars are used for the biosynthesis of cell wall carbohydrates, the degradation of the cell wall during ripening provides substrates for the synthesis of ascorbic acid and could explain the increase in ascorbic acid in 'Golden' papaya (Conklin, 2001; Wolucka and Van Montagu, 2003). Mondal et al. (2004) found that tomatoes respond to increased oxidative stress by raising their ascorbic acid content.

The SS (Table 1) did not significantly change during storage. According to Zhou and Paull (2001), the sugar content in papaya remains constant after harvest because papaya fruits do not accumulate hydrolyzable starch during fruit ripening (Selvaraj et al., 1982). The acidity of the papaya in our study increased during the ripening process (Table 1); according to Paull et al. (1999), such an increase may be due to the release of galacturonic acid from the cell wall.

The results revealed that there was variation in the activity of antioxidant enzymes, with peaks of lipid peroxidation during the ripening of 'Golden' papaya. These results provide a basis for future research, especially with regard to the relationship among the climacteric stage, the activation of antioxidant enzymes and the role of APX in papaya ripening.

Acknowledgment: We acknowledge the São Paulo Research Foundation (FAPESP) for scholarship to Evellyn C.0. Resende. 


\section{REFERENCES}

Andrews PK, Fahy DA, Foyer CH (2004) Relationships between fruit exocarp antioxidants in the tomato (Lycopersicum esculentum) high pigment-1 mutant during development. Physiol. Plant. 120:519-528.

Azevedo RA, Alas RM, Smith RJ, Lea PJ (1998) Response of antioxidant enzymes to transfer from elevated carbon dioxide to air and ozone fumigation, in the leaves and roots of wild-type and a catalase-deficient mutant of barley. Physiol. Plant. 104:280-292.

Biale JB, Young RE (1982) Respiration and ripening in fruits - retrospect and prospect. In: Friends J, Rhodes MJC (eds), Recent advances in the biochemistry of fruit and vegetables, pp.1-39. Academic Press, London.

Bradford MM (1976) A rapid and sensitive method for the quantitation of microgram quantities of protein utilizing the principle of protein-dye binding. Anal. Biochem. 72:248-254.

Bron IU, Jacomino AP (2006) Ripening and quality of 'Golden' papaya fruit harvested at different maturity stages. Braz. J. Plant Physiol. 18:389-396.

Bron IU, Jacomino AP (2009) Ethylene action blockade and cold storage affect ripening of 'Golden' papaya fruit. Acta Physiol. Plant. 31:1165-1173.

Bron, IU, Jacomino AP, Pinheiro AL (2006) Influence of ripening stage on physical and chemical attributes of 'Golden' papaya fruit treated with 1-methylcyclopropene. Bragantia 65:553-558.

Camejo D, Martí MC, Román P, Ortiz A, Jiménez A (2010) Antioxidant system and protein pattern in peach fruits at two maturation stages. J. Agric. Food Chem. 58:11140-11147.

Carvalho CRL, Mantovani DMB, Carvalho PRN, Moraes RMM (1990) Análises químicas de alimentos, Ital, Campinas.

Conklin PL (2001) Recent advances in the role and biosynthesis of ascorbic acid in plants. Plant Cell Environ. 24:383-394.

Del Río LA, Pastori GM, Palma JM, Sandalio LM, Sevilla F, Corpas FJ, et al. (1998) The activated oxygen role of peroxisomes in senescence. Plant Physiol. 116:1195-1200.

Dhindsa RS, Plum-dhindsa P, Reid DM (1982) Leaf senescence and lipid peroxidation: effects of some phytohormones, and scavengers of free radicals and singlet oxygen. Physiol. Plant. 56:453-457.

Dhindsa RS, Plumb-dhindsa P, Thorpe TA (1981) Leaf senescence:correlated with increased levels of membrane permeability and lipid peroxidation, and decreased levels of superoxide dismutase and catalase. J. Exp. Bot. 32:93-101.

Du Z, Bramlage WJ (1994) Superoxide dismutase activities in senescing apple fruits (Malus domestica Borkh.). J. Food Sci. 59:581-584.

Ferrie BJ, Beaudoin N, Burkhart W, Bowsher CG, Rothstein SJ (1994) The cloning of two tomato lipoxygenase genes and their differential expression during fruit ripening. Plant Physiol. 106:109-118.

Fogelman E, Kaplan A, Tanami Z, Ginzberg I (2011) Antioxidative activity associated with chilling injury tolerance of muskmelon (Cucumis melo L.) Rind. Sci. Hortic. 128:267-273.

Gomes-Junior RA, Moldes C, Delite FS, Pompeu GB, Gratão PL, Mazzafera $P$, et al. (2006) Antioxidant metabolism of coffee cell suspension cultures in response to cadmium. Chemosphere 65:1330-1337.

Huang R, Xia R, Hu L, Lu Y, Wang M (2007) Antioxidant activity and oxygen-scavenging system in orange pulp during fruit ripening and maturation. Sci. Hortic. 113:166-172.
Jacomino AP, Kluge RA, Brackmann A, Castro PRC (2002) Ripening and senescence of papaya with 1-methilcyclopropene. Sci. Agric. 59:303-308.

Kanazawa S, Sano S, Koshiba T, Ushimaru T (2000) Changes in antioxidative enzymes in cucumber cotyledons during natural senescence: comparison with those during dark-induced senescence. Physiol. Plant. 109:211-216.

Kraus TE, Mckersie BD, Fletcher RA (1995) Paclobutrazol-induced tolerance of wheat leaves to paraquat may involve increased antioxidant enzyme activity. J. Plant Physiol. 145:570-576.

Lee DH, Lee CB (2000) Chilling stress-induced changes of antioxidant enzymes in the leaves of cucumber in gel enzyme activity assays. Plant Sci. 159:75-85.

Leshem YY, Halevy AH, Frenkel C, Frimer AA (1986) Oxidative processes in biological systems and their role in plant senescence. In: Leshem YY, Halevy AH, Frenkel C (eds), Processes and control of plant senescence: developments in crop science, pp.84-99. Elsevier, Amsterdam.

Lester G, Stein E (1993) Plasma membrane physicochemical changes during maturation and postharvest storage of muskmelon fruit. J. Am. Soc. Hortic. Sci. 118: 223-227.

Lurie S, Ben-Arie R (1983) Microsomal membrane changes during the ripening of apple fruit. Plant Physiol. 73:636-638.

Masia A (1998) Superoxide dismutase and catalase activities in apple fruit during ripening and post-harvest and with special reference to ethylene. Physiol. Plant. 104:668-672.

Masia A, Ventura M, Gemma H, Sansavini S (1998) Effect of some plant growth regulator treatments on apple fruit ripening. Plant Growth Regul. $25: 127-134$.

Meir S, Philosoph-Hadas S, Zauberman G, Fuchs Y, Akerman M, Aharoni N (1991) Increased formation of fluorescent lipid-peroxidation products in avocado skins precedes other signs of ripening. J. Am. Soc. Hortic. Sci. 116:823-826.

Mihara M, Uchiyama M, Fukuzawa K (1980) Thiobarbituric acid value on fresh homogenate of rat as a parameter of lipid peroxidation in aging, $\mathrm{CCl}_{4}$ intoxication, and vitamin e deficiency. Biochem. Med. 23:302-311.

Mondal K, Malhotra SP, Jain V, Singh R (2009) Oxidative stress and antioxidant systems in guava (Psidium guajava L.) fruits during ripening. Physiol. Mol. Biol. Plants. 15:327-334.

Mondal K, Sharma NS, Malhotra SP, Dhawan K, Singh R (2004) Antioxidant systems in ripening tomato fruits. Biol. Plant. 48:49-53.

Nakano Y, Asada K (1981) Hydrogen peroxide is scavenged by ascorbatespecific peroxidase in spinach chloroplast. Plant Cell Physiol. 22:867-880.

Palma T, Marangoni AG, Stanley DW (1995) Environmental stress affect tomato microsomal membrane function differently than natural ripening and senescence. Postharvest Biol. Technol. 6:257-273.

Paull RE, Gross K, Qiu Y (1999) Changes in papaya cell walls during fruit ripening. Postharvest Biol. Technol. 16:79-89.

Purvis AC, Shewfelt RL, Gegogeine JW (1995) Superoxide production by mitochondria isolated from green bell pepper fruit. Physiol. Plant. 94:743-749.

Reddy YV, Srivastava GC (2003) Superoxide dismutase and peroxidase activities in ripening mango (Mangifera indica L.) fruits. Indian J. Plant Physiol. 8:115-119.

Rich PR, Bonner WD (1978) The sites of superoxide anion generation in higher plant mitochondria. Arch. Biochem. Biophys. 188:206-213. 
Rogiers SY, Kumar GNM, Knomles NR (1998) Maturation and ripening of fruit of amelanchier alnifolia nutt. are accompanied by increasing oxidative stress. Ann. Bot. 81:203-211.

Romani RJ (1984) Respiration, ethylene, senescence, and homeostasis in an integrated view of postharvest life. Canadian J. Bot. 62:2950-2955.

Saltveit ME (1993) Internal carbon dioxide and ethylene levels in ripening tomato fruit attached to or detached from the plant. Physiol. Plant. 89:204-210.

Selvaraj Y, Subramanyan MD, lyer CPA (1982) Changes in the chemical composition of four cultivars of papaya (Carica papaya L.) during growth and development. J. Hortic. Sci. 57:135-143.

Silva E, Lourenço EJ, Neves VA (1990) Soluble and bound peroxidases from papaya fruit. Phytochemistry. 29:1051-1056.

Singh R, Dwivedi UN (2008) Effect of ethrel and 1-methylcyclopropene (1-MCP) on antioxidants in mango (Mangifera indica var. Dashehari) during fruit ripening. Food Chem. 111:951-956.
Tatagiba JS, Liberato JR, Zambolim L, Ventura JA, Costa H (2002) Control and favourable weather for anthracnose of papaya. Fitopatol. Bras. 27:186-192.

Thompson JE (1984) Physical changes in the membranes of senescing and environmentally stressed plant tissues. In: Shinitzky M (ed), Physiology of membrane fluidity, pp. 85-108. CRC Press, Boca Raton.

Tucker GA (1993) Introduction. In: Seymour GB, Taylor JE, Tucker GA (eds), Biochemistry of fruit ripening, pp. 1-51. Chapman \& Hall London, London.

Wolucka BA, Van montagu M (2003) Gdp-mannose 3',5'-epimerase forms gdp-I_gulose, a putative intermediate for the novo biosynthesis of vitamin c in plants. J. Biol. Chem. 278:47483-47490.

Zhou L, Paull RE (2001) Sucrose metabolism during papaya (Carica papaya $\mathrm{L}$ ) fruit growth and ripening. J. Am. Soc. Hortic. Sci. 126:351-357. 